\title{
Monocultural Education in a Multicultural Society: The case of Teacher Preparation in Botswana
}

\author{
Annah Anikie Molosiwa \\ The University of Botswana \\ Botswana
}

In several policy documents reviewing the country's education system, the Ministry of Education has made noteworthy pronouncements on how to improve teacher education in Botswana. This mainly concerns equipping teachers with pedagogical skills to better address the learning needs of the linguistically and culturally diverse student population. Even though at policy level it is acknowledged that Botswana is a multicultural society, at implementation stage there is no such evidence. This article argues that lack of implementation of policy pronouncements contradicts the government's aspirations to provide equal learning opportunity to all learners. The infusion of courses in multicultural education at teacher education level is seen as an alternative.

\author{
Introduction \\ Geography and Language \\ Description of Language Education Programs \\ Literature Review \\ Policy Pronouncements on Teacher Education \\ Conclusion \\ Notes \\ References
}

\section{Introduction}

While the government of Botswana has made resources available to support the education of teachers, attempts to prepare teachers with the skills to better address the learning needs of the linguistically and culturally diverse student population in schools still remains inadequate. This contradicts the country's aspirations to provide equal educational opportunity to all citizens by the year 2016 (Republic of Botswana, 1997). The aim to increase access and equity at primary and secondary school levels and to improve the quality of education is pronounced in many policy documents such as the 1994 Revised National Policy on Education (RNPE) and Vision 2016 Report. Despite these policy pronouncements, the high rate of failure and school dropout continues to escalate, especially in remote areas of the country. This is attributed to several factors: the insensitivity of the school culture and curriculum to the culture and 
learning styles of children from ethnic minority groups, negative relations between teachers and pupils or between pupils and their peers, language difficulties and ethnic intolerance (Hays, 2002; Polelo, 2003; Mokibelo \& Moumakwa, 2006). In view of these findings, this paper argues that the current education system is not inclusive of the cultural and ethnic minority groups in the country; it serves certain children and excludes others.

Teachers are trained as if Botswana society is monocultural. However, many students come to school with diverse linguistic backgrounds and experiences that are not part of the official school knowledge (more details provided later). They attain literacy in English and Setswana, which are not their home languages. The cultural linguistic diversity of the students is mentioned in the curriculum and other policy documents, but teacher preparation does not seem to address issues of multiculturalism, especially in Setswana courses. The monocultural notion of teacher education is evident in many ways.

I recall an informal discussion I once had with a curriculum development officer about the bias of some Setswana examination questions towards ethnic minority students. I had pointed out some weaknesses in a past examination paper for junior secondary students, for which ethnic minority students might have had difficulty in responding to certain questions because of the unfamiliar vocabulary that was used. The officer disagreed with me and insisted that;

This was a Setswana examination, not Setswana as a second language examination. All students have been studying this syllabus and are expected to know the vocabulary used. Until such time that there is a Setswana as a second language syllabus, there is nothing we can do about students to whom Setswana is a second language (N. R., personal communication, November, 2003).

By uttering these words, the officer was indirectly admitting that the curriculum did not make provision for linguistic minority students. Ethnic minorities in Botswana have for a long time been regarded as inferior, which surfaces frequently in school settings. In many classrooms and schools across the country, it is common to hear teachers or mainstream students uttering remarks such as these to ethnic minority students: "That's the Sesarwa way, or the Shekgalagari way, say it in Setswana. That's not Setswana but Ikalanga pronunciation" (Sesarwa, Shekgalagari and, Ikalanga are some of the minority languages of Botswana). This kind of derisive expression is embedded in everyday discourse, not only in Setswana classrooms but also in different social gatherings.

Drawing from government policy documents, research reports, the literature about education and ethnic minorities in the country and my experiences as a teacher and teacher educator in Botswana during the last 25 years, I will describe the geography and language situation of Botswana and language education programs for prospective teachers, discuss related literature and pronouncements in government policy documents on multiculturalism in the 
country, and make recommendations for improving teacher education in Botswana.

\section{Geography and Language}

Botswana is a landlocked, semi-arid country of 582,000 square kilometers, about the same size as Kenya and France. It is located in the interior of Southern Africa and is bordered by Zambia, Zimbabwe, Namibia, and South Africa. It attained self-governance in 1965 after 80 years as a British Protectorate and became independent on September 30,1966. Botswana is a multilingual state with an estimated number of at least 25 languages. Research has not ascertained the exact number of languages in the country because of the blurred distinction between a language and a dialect (Batibo \& Smieja, 2000). Setswana is demographically the most dominant language in the country. It is spoken by at least $80 \%$ of a population of $1,680,863$ either as mother tongue or as a second language according to the Botswana Statistics Office updates from the 2001 Census (Republic of Botswana, 2001). The estimate of the population has been further considered and rectified by the World Bank to be standing at 1,904,991 (World Bank, 2008). The World Bank figures are acceptable in that they use several demographic processes indicators from the UNDP, WHO, and other advanced projections derived from local processes. Setswana is the medium of instruction during the first two years at primary school and is offered as a compulsory school subject at both primary and secondary school levels. English is the medium of instruction for all subjects at primary and secondary school levels except for Setswana. Other languages spoken in the country but not recognized officially are Ikalanga (11\%), Otjiherero (2.2\%), Shiyeyi $(1.4 \%)$, Thimbukushu $(0.6 \% 0$, Sesubiya $(0.5 \%)$, Shekgalagari $(1.1 \%)$, different varieties of Khoesan languages making $2.8 \%$ and Afrikaans spoken by $0.2 \%$ of the population (Batibo, Mathangwane, \& Mosaka, 1997 ${ }^{1}$ ). These languages are spread out in the North, Northeast, Northwest, West and South of the country respectively.

The geographical location of the different ethnic groups in the country determines the kind of students found in a particular school. For instance, most schools in the northeastern region of the country are predominantly populated by Ikalanga-speaking students, while those in the western region are mostly Bakgalagadi and Khoesan speakers. Many teachers from the mainstream Setswana-speaking groups do not want to serve in some of these regions because of language and cultural barriers.

Botswana shares the experience of foreign rule with the rest of the African continent. At independence in 1966, the government banned the use of local languages other than Setswana and English in education, the media, and all other social domains. Prior to independence, code-switching occurred not only into Setswana but also into other native languages of the pupils whenever the teacher happened to be a member of the community in which he or she was 
teaching. Some commonly cited examples of teachers who code-switched between Setswana and the children's home languages were the Ikalangaspeaking teachers in Northeast district and Afrikaans-speaking teachers in Southern Kgalagadi district. After independence, Setswana was accepted as the medium of instruction for the first 2 to 3 years at primary school level. The transition to the medium of English varied according to the language competence of the teacher, and it was not uncommon to find some instruction through Setswana even in Standard 7 (Republic of Botswana, 1977). From Standard 4 onwards, however, English was the official medium of instruction while Setswana was offered only as a subject. Actual classroom practices indicated that teachers actually code-switched between Setswana and English throughout the primary school.

To upgrade the quality of teachers, more efforts and resources were allocated towards the improvement of the teaching of English as the medium of instruction. English was also allocated more periods on the school timetable than Setswana (Republic of Botswana, 1977, 1985). The language in education policy favored English to the detriment of Setswana and extinction of other local languages. The reality that the country needed English for international relations was wrongly translated into giving it absolute priority over the national language. The distinction between studying English as a subject and studying through its medium was never made. It was assumed that by learning through the medium of English, Batswana children would acquire the language better. The policy instituted subtractive bilingualism instead of additive bilingualism. In additive bilingualism, a second language and culture do not displace the first language, and this has been associated with educational advantages and enhanced metalinguistic development (Cummins, 2000). Contrary to this, subtractive bilingualism occurs when the acquisition of a second language and culture take place at the expense of the first language, which, according to Cummins, has been associated with disabling educational settings for language minority speakers.

The language in education policy in Botswana affects children from ethnic minority groups negatively, as they are the ones who have the highest failure rate in Primary School Leaving Examinations and the highest dropout rates (NyatiRamahobo, 2006). Nyati-Ramahobo has also observed that while the Batswana children learn in Setswana about their history and culture, non-Setswana speaking children learn in Setswana about Tswana cultures and traditions, ultimately learning to look down on their traditions, languages, and customs. The non-recognition of these local languages means eradication of their cultures (Jeremiah, 2008) and the death of the knowledge embedded in them (NyatiRamahobo, 2006). It is vital that Batswana children be educated through local languages [alongside English] to enable them to participate in national development and in the understanding of any issues of local and national importance (Adeyemi, 2008; Molosiwa, 2005). 


\section{Language Education Programs}

Until 2003, language education programs for pre-service teachers did not address issues of educating culturally and linguistically diverse learners. Emphasis was on teaching trainees how to teach literature and language (grammar). Topics that were emphasized in the language education courses were:

- Communicative approaches to the teaching of grammar, basic language skills of reading, writing, speaking, and listening;

- Ways of teaching literature;

- Selection and evaluation of instructional materials for language and literature;

- Remedial teaching and mixed ability teaching; and

- Preparation of schemes of work and lesson plans.

These topics were based on content taught at the junior and senior secondary schools, and therefore emphasis was on giving teachers the skills to handle the syllabi. It was only in 2003 that the topic "Culturally Relevant Teaching" was included in one language education course for pre-service teachers. A fully fledged course on Multicultural Education was also introduced for in-service teachers. Prior to this, issues of diversity were relegated to courses in Social Studies. Even now, there are some teacher trainees who finish their programs without any exposure to multicultural education issues. Teacher education is handled at three different levels in Botswana. There are colleges of education that offer a Diploma (equivalent to the US associate degree) in Primary Education and those that offer a Diploma in Secondary Education. The duration of teacher preparation for both these programs is three years. The only institution that awards a degree in teacher education is the University of Botswana. Teacher preparation at the university lasts for five years. Students spend the first four years in the Faculty of Humanities studying content in different subject matter and are awarded a bachelor's degree; they then spend another year in the Faculty of Education to study education courses. Contrary to the university program, language education programs at the colleges do not offer any courses in multicultural education or teach about culturally relevant pedagogy. This suggests that there are many teachers in schools who are poorly equipped with the skills for working in multicultural classrooms. Even some who go through the university program do not take the course on multicultural education since it is not compulsory. The only students who benefit from it are those who choose to study it.

The education system in Botswana is built on the national principles of democracy, self-reliance, unity, and kagisano (peaceful coexistence). By providing free education and a uniform curriculum in all schools, the government 
believes that it is being democratic to its citizens. Issues of linguistic and cultural diversity have been neglected for a long time; assimilating minorities into the mainstream language and culture has been the norm. Teachers are seen as implementers of the standardized curriculum, not necessarily advocates for social justice. The need to instill certain humane characteristics in prospective teachers in order for them to empathize with students and be reflective practitioners is taken for granted. All students are presumed the same and taught in the same way. In this regard, a "one size fits all" approach to curriculum, instruction, and assessment is assumed to equate with equity for all (CochranSmith, 2003). Teacher competence is measured by the performance of the students in examinations. A teacher (or a school) that produces students who have obtained high grades is considered good; adequacy of teacher preparation to teach diverse students is an issue that is neglected, yet examination results have indicated that schools in remote areas perform unsatisfactorily in national examinations as compared to those in mainstream villages and towns. Some survey reports and studies have shown that teachers do not have the skills to teach effectively in remote area schools (Hays, 2002; Mokibelo \& Moumakwa, 2006; Polelo, 2003). Based on studies conducted among ethnic minority groups of the Basarwa, Hays (2002) revealed that many ethnic minority students in primary schools in remote areas dropped out of school in Botswana because of the insensitivity of the school culture and curriculum to their culture and learning styles. In Hays' (2002) words, children performed badly in examinations and dropped out of school because they were:

Taught foreign systems of knowledge in a language or language variety other than their own, by teachers from cultures that are different from, and dominant to their own, and who use instruction and disciplinary styles that do not match that of the students' home life (p.1).

Polelo (2003) concurs with Hays that language difficulties, ethnic intolerance, negative relations between students and their teachers and between students and their peers are causes of school dropout for remote area children. In a study to investigate challenges faced by Khoe children in reading English textbooks, Mokibelo and Moumakwa (2006) also found that the children's reading level was very low. Overall, teachers were found to be negative towards the Khoe children as compared to their Setswana speaking counterparts:

The teachers felt that Khoe children have a negative attitude towards school in general and reading in particular, and consequently, are not teachable (p.70).

Based on the above studies, one would conclude that teachers lack the skills to teach children from ethnic minority groups. There is no child who deserves to be labeled "not teachable" unless there is something wrong with the teacher. Issues about learning difficulties faced by remote area dweller children have long been raised in a government-funded consultancy on "Primary Schooling for Remote Area Dwellers" (Tabachnick, 1980). Tabachnick looked beyond the classroom and argued that circumstances of living, culture, economic and social mobility for remote area dweller children were different than for most 
Batswana. He cited lack of appropriate teaching materials as obstructive to the learning of these children. He pointed out that in remote areas, there is less access to and less variety of informal learning opportunities through mass media and the interchange of news and ideas.

The foregoing literature confirms that the linguistic and cultural differences among students are neglected by the education system. It is acknowledged that Botswana has national curricula mandated by the Ministry of Education to be taught in all schools. Although teachers are free to choose modes of teaching, the curricula have prescribed content and forms of assessment. This limits any flexibility for decision-making either by the schools or individual classroom teachers, thus overlooking the linguistic and cultural diversity of the learners, an important factor in culturally relevant pedagogy. Culturally relevant pedagogy has been defined by a number of researchers as an effective means of meeting the academic and social needs of culturally diverse students (Gay, 2000; LadsonBillings, 2001). Gay (2000) asserts that culturally relevant pedagogy uses:

...the cultural knowledge, prior experiences, frames of reference, and performance styles of ethnically diverse students to make learning more relevant to and effective [for students].... It teaches to and through strengths of these students. it is culturally validating and affirming (p. 29).

The above is echoed by Ladson-Billings $(2001,2006)$ who states that culturally relevant teachers display a willingness to nurture and support cultural competence through characteristics such as understanding culture and its role in education, taking responsibility for learning and about students' culture and community, using students' culture as a basis for learning, and promoting a flexible use of students' local and global culture.

The state of affairs in Botswana schools dictates that culturally relevant pedagogy and multicultural education be considered as part of the teacher education curriculum. Biseth (2009) argues that all democratic countries must take into consideration multilingualism, as it "broadens the repertoire for interaction and promotes mutual respect, tolerance and equality, which are key democratic values" (p.13). Although not implemented, the government of Botswana, through policy documents, has acknowledged that Botswana is a multilingual and multicultural nation. Pronouncements have been made on how teacher education would be improved in view of the linguistically and culturally diverse student population in schools. The section that follows gives an overview of these pronouncements.

\section{Policy Pronouncements on Teacher Education}

The government has pronounced education reforms in many policy documents. The first national commission to review the education system was set up in 1977. It came up with a report known as Education for Kagisano. The commission made several recommendations about pre-service teacher 
education. One particular recommendation that could have made a difference in the caliber of teachers produced, had it been implemented, read: "Rather than study the theoretical foundations of education in terms of sociology, philosophy and psychology, the student teachers would find it more useful to study the actual situation in Botswana society, among Batswana children and in Botswana schools." Focus should be on the discussion of questions such as:

- What are the characteristics of homes in Botswana?

- What kinds of social and educational needs do the teacher trainees observe in their pupils during their year of probationary teaching?

- What are the implications of the national principles for Botswana's schools?

- How can cooperation with the home be best arranged?

- What kinds of social relationships are there between pupils, between teachers, and between pupils and teachers in a school?

- How can discipline best be maintained in the classroom?

(Republic of Botswana, 1977, pp. 152-153).

The commission believed that, by addressing issues such as the above, the students' study of the sociology of education and of child psychology could help them to interpret and enrich their own experiences. Student teachers could also use their practical experience to elucidate theory. Unfortunately, this recommendation was never implemented.

Considering the time that had elapsed since the last Commission, the government found it appropriate to conduct another review of the entire education system with a view to developing a system that would see the country into the 21st century (Republic of Botswana, 1994). Another commission was therefore set up in 1993. This commission came up with a report known as the Revised National Policy on Education in 1994 (RNPE 1994). To the dismay of those who embrace the tenets of multiculturalism, RNPE did not come up with anything specific about minority groups or remote area dwellers, except the following recommendation that was later deferred when final recommendations were passed:

With respect to the teaching of languages in primary school, the Commission recommends that: Where parents request that other local languages be taught to their children, the schools should make arrangements to teach them as a co-curricular activity. (REC.18, para.4.7.31)

The recommendation was deferred on the reasoning that it could result in undue pressure on schools to offer the various languages spoken in Botswana while the schools lacked the capacity to do so and the education system would not be able to support such a development. Further, it was said to be contrary to national language policy. 
The next document that outlines education reforms is Vision 2016. This document presents a long-term vision for Botswana when it will have been an independent nation for 50 years. When the country celebrated the 30th anniversary of independence in 1996, the government set upon a task to take stock of the country's past aspirations and the extent to which they have been realized, and thus formulated this vision. The vision addresses all aspects affecting the life of the society nationally and globally. Among the aspirations that have implications for teacher education is the one that reads;

By the year 2016, Botswana will have a system of quality education that is able to adapt to the changing needs of the country as the world around us changes. Improvements in the relevance, the quality, and access to education lie at the core of the vision for the future... Botswana's wealth of different languages and cultural traditions will be recognized, supported and strengthened within the education system. No Motswana will be disadvantaged in the education system as a result of a mother tongue that differs from the country's two official languages. (Republic of Botswana, 1997 , p. 5)

An examination of the current state of affairs indicates that these ideals of the vision will not be achieved by the year 2016. Practically, no provision has been made to introduce other local languages in schools in terms of resources or teacher training.

Looking across the various policy documents, it becomes apparent that none of them raises the question of minorities being underrepresented in the teaching force. This came up only during an international conference held at the University of Botswana in September, 2003, titled 'Research for Khoesan Development." As a way forward to include the Khoesan in the education system, the participants proposed that:

- Affirmative action should be taken to train Khoesan teachers.

- Mother language instruction should be introduced in schools especially for the first years of primary schooling.

- There should be retraining and orientation of teachers, education officers about Khoesan issues/communities/culture to address the problem of negative attitudes, prejudices, misconceptions, etc.

- A quota system should be established for the Khoesan, for entry at colleges of education and other tertiary institutions.

- Multicultural education should be infused in all teaching and learning programs.

It is regrettable to note that the above recommendations that seemed appropriate for a multicultural society were not put to practice by colleges of education. Apparently, education reform proposals do not move beyond political rhetoric into real changes in the education system. One would expect schools, particularly teacher education institutions, to use the reports of education commissions and 
conferences to guide their curriculum, but this does not seem to be the case. The 1994 Commission $^{2}$ states that it did gather information through a variety of means, including visits to every district in Botswana to get first-hand evidence and observe the education system in operation. Even then, it appears as though teachers were not consulted. Echoing teachers' lack of awareness of issues that affect them, Mannathoko (1998) laments that in Botswana too much of the relevant knowledge and research is invisible to teachers. She blames research institutions and policy makers for not having strategies in place to expose the information to teachers and this is still the case even now.

Policy pronouncements about linguistic and cultural differences are in line with international practices. The need for prospective teachers to learn about students, their cultures, and communities and to build on such knowledge in teaching and learning has been found to be crucial in other parts of the world (Nieto, 2004; 2005; Delpit, 2002). In the United States, there is some concern about the teaching force that is dominated by teachers whose racial, cultural, and socio-economic background is different from that of the students they teach. Such teachers are purported to be inadequately prepared to teach children different from themselves. Similarly in Botswana, it has been found out that the school culture and the curriculum are insensitive to the culture and learning styles of children from ethnic minorities (Hays, 2002; Polelo 2003).

\section{Conclusion}

Policy proposals to reform teacher education in Botswana have not been implemented. As a result, the education system serves certain students and excludes others. There is need to rethink teacher education programs so as to equip teachers with pedagogical skills to better address the learning needs of the linguistically and culturally diverse student population in schools. In order for multicultural education to be implemented effectively, there is need for teachers and administrators to attend to issues such as content integration, the knowledge construction process, prejudice reduction, equity pedagogy, and an empowering school culture (Banks \& Banks, 2006; Banks, 1995; Cochran-Smith, 2003). Multiculturalism as an educational policy is necessary to guarantee educational opportunities and to level the existing social inequalities in education. Therefore, the following is recommended:

- Multicultural education should be infused in all teacher education programs especially in language courses;

- Issues about diversity should be core in all teacher education programs. Topics such as social justice, teacher knowledge, beliefs and attitudes, and teacher learning should be infused in the curriculum.

- Prospective teachers should be afforded opportunities to spend some time during practice teaching in remote area schools to gain experiences of cultures different from their own. 
- In view of the recommendation that by the year 2016 all local languages will be taught in school, the University of Botswana should introduce language courses for local languages that are not currently taught. Some of these languages are already taught in neighboring countries such as Namibia at university level. Arrangements can be made to send interested students to study there.

- Teacher education faculty should embark on research with teachers serving in remote area schools to document the cultural life styles of the communities as well as learning and teaching difficulties encountered in those areas. Such research could be compiled into booklets and published to be used as resource materials in the courses taught.

- As recommended at the conference for "Khoesan Development" in September, 2003, affirmative action should be taken to train teachers from ethnic minority groups.

- In-service training should be provided for serving teachers and education officers about issues of linguistic and cultural diversity and culturally relevant teaching to address the problem of negative attitudes, prejudices, and misconceptions about minorities.

\section{Notes}

1. More recent statistics is not available to the author's knowledge.

2. The same as above.

\section{References}

Adeyemi, D. A. (2008). Bilingual education: Meeting the challenges of diversity in Botswana. Nordic Journal of African Studies. 17(1), 20-33.

Banks, J. A., \& Banks, C. M. (Eds.). (2006). Multicultural education: Issues and perspectives (6th ed.). Hoboken, NJ: Wiley.

Banks, J. A. (1995). Multicultural education: Historical development, dimensions, and practice. In J. A. Banks \& C. A. M. Banks (Eds.). Handbook of research on multicultural education (pp. 3-24). New York: Macmillan.

Batibo, H. M. \& Smieja, B. (Eds.) (2000). Botswana: The future of the minority languages. Frankfurt am Main, Germany: Peter Lang.

Batibo, H. M., Mathangwane, J. T., \& Mosaka, N. M. (1997). Prospects for sociolinguistic research undertaking in Botswana: Priorities and strategies. In B. Smieja (Ed.) Languages in contact and conflict in Africa (LiCCA): Proceedings of the LiCCA Workshop in Dar es Salaam (pp. 27-36). Duisburg, Germany: Gerhard Mercator University. 
Biseth, H. (2009). Multilingualism and education for democracy. International Review of Education. 55(1), 5-20.

Cochran-Smith, M. (2003). The multiple meanings of multicultural teacher education: A conceptual framework. Teacher Education Quarterly, 53(1), 3-5.

Cummins, J. (2000). Language, power, and pedagogy. Bilingual children in the crossfire. Clevedon, England: Multilingual Matters.

Delpit, L. D. (2002). The skin that we speak: Thoughts on language and culture in the classroom. New York: New Press.

Gay, G. (2000). Culturally responsive teaching: Theory, research, and practice. New York: Teachers College.

Hays, J. (2002). Education and the San of Southern Africa: The search for alternatives. In Mazonde, I. N. (Ed.). Minorities in the millennium: Perspectives from Botswana (pp. 73-87). Gaborone, Botswana: Lightbooks.

Jeremiah, K. (2008). The use of Setswana as a medium of instruction, a core subject and a national language: Is it not negation of affirmative action? A study of Botswana linguistic situation. Language in India, 8(11), 399-415. Retrieved April 23, 2009, from www.languageinindia.com

Ladson-Billings, G. (2001). Crossing over to Canaan: The journey of new teachers in diverse classrooms. San Francisco: Jossey-Bass.

Ladson-Billings, G., (Ed.) (2006). Education research in the public interest: Social justice, action, and policy. New York: Teachers College Press.

Mannathoko, C. (1998). Obstacles to, and possibilities for, democratic teacher education in Botswana. In C. Harber, (Ed.). Voices of democracy: $A$ north-south dialogue on education for sustainable democracy (pp. 71-83). Sandiacre: UK: Education Now Publishing Co-operative.

Mokibelo, E. B., \& Moumakwa, T. V. (2006). An investigation into challenges faced by Khoe children in reading English language school texts: Motshegaletau primary school. An unpublished research report. A study funded by UBTROMSO, Gaborone, Botswana.

Molosiwa, A. A. (2005). Extinction or distinction? Empowering local languages in Botswana. In R. H. Hopson \& B. Brock-Utne (Eds.). Languages of instruction for African emancipation (pp. 175-198). Cape Town, South Africa: CASAS.

Nieto, S. (2004). Affirming diversity: The sociopolitical context of multicultural education. Boston: Allyn \& Bacon.

Nieto, S. (2005). Social justice in hard times: Celebrating the vision of Dr. Martin Luther King, Jr. Multicultural Perspectives, 7(1), 3-7. 
Nyati-Ramahobo, L. (2006). The long road to multilingual schools in Botswana. In O. Garcia, T. Skutnabb-Kangas \& M. E. Torres-Guzman (Eds.). Imagining multilingual schools: Languages in education and glocalization. (pp. 200222). Clevedon, England: Multilingual Matters.

Polelo, M. (2003). Minorities on the margins: School dropout in remote areas of western Botswana. An unpublished paper presented at the "Research for Khoe and San Development. University of Botswana. 10-12 September, 2.

Republic of Botswana, (1977). The report of the National Commission on Education. Gaborone, Botswana: Government Printer.

Republic of Botswana, (1985). Botswana up to date. Department of Information and Broadcasting. Gaborone, Botswana: Government Printer.

Republic of Botswana, (1994). The revised national policy on education, Gaborone, Botswana: Government Printer.

Republic of Botswana, (1997). Long term vision for Botswana - Towards prosperity for all. Vision 2016. Gaborone, Botswana: Government Printer

Republic of Botswana, (2001). Botswana in figures. Central Statistics Office. Gaborone, Botswana: Department of Printing and Publishing Services.

Tabachnick, B. R. (1980). Primary schooling for remote area dwellers in Botswana. [Report of a consulting visit to Botswana]. Madison, WI: University of Wisconsin.

World Bank, (2008). World development indicators, Retrieved November 16, 2009, from http://go.worldbank.org/8P9IVY6270 